\title{
Association Between Infection With Campylobacter Species and the Risk of Esophageal Cancer: A Hospital-Based Case-Control Study in Thailand
}

\section{Arisara Poosari}

Khon Kaen University Faculty of Medicine

Thitima Nutravong ( $\nabla$ thicha@kku.ac.th )

Khon Kaen University Faculty of Medicine

Prakasit Sa-ngiamwibool

Khon Kaen University Faculty of Medicine

Wises Namwat

Khon Kaen University Faculty of Medicine

\section{Supaporn Chatrchaiwiwatana}

Khonkaen University Faculty of Dentistry

Piti Ungareewittaya

Khon Kaen University Faculty of Medicine

\section{Research}

Keywords: Campylobacter species, poor oral hygiene, risk factor, esophageal cancer

Posted Date: June 2nd, 2021

DOl: https://doi.org/10.21203/rs.3.rs-545646/v1

License: (9) (i) This work is licensed under a Creative Commons Attribution 4.0 International License.

Read Full License

Version of Record: A version of this preprint was published at European Journal of Medical Research on July 31st, 2021. See the published version at https://doi.org/10.1186/s40001-021-00561-3. 


\section{Abstract \\ Background}

Previous studies have shown the association between Campylobacter species infection and environmental factors, poor oral hygiene in particular, is linked to an increased risk of esophageal cancer (EC). However, no study has reported on these factors in Thai. Thus, this study objective was to evaluate the impact of the relationship between Campylobacter infection and environmental factors on EC incidence in the population Thailand.

\section{Methods}

Data from a case-control study were collected from 105 newly diagnosed EC cases and 105 controls recruited from 2007 to 2017. Infection with Campylobacter spp. was detected in the Formalin-fixed paraffin-embedded (FFPE) tissue of EC taken from gastroesophageal biopsy specimens obtained from the participants and evaluated using a TaqMan ${ }^{\circledR}$ real-time PCR. Multivariable logistic regression was performed to calculate the odds ratios (ORs) and perform data analysis.

\section{Results}

Smoking, alcohol use, a family history of cancer, history of gastroesophageal reflux disease, poor oral hygiene and Campylobacter spp. infection were shown to be significant risk factors for $E C(p<0.05)$. The combination of poor oral hygiene and infection with Campylobacter spp. constituted significant risk for EC $(p<0.001)$. In addition, the risk of EC in subjects co-infected with $C$. rectus and $C$. concisus practiced poor oral hygiene was even higher and was significant (ORadj $=4.7,95 \% \mathrm{Cl}: 2.41-9.98, \mathrm{p}=0.003$ ).

\section{Conclusions}

In Thailand, poor oral hygiene and infection with Campylobacter spp. was associated with an increased risk of EC.

\section{Introduction}

Esophageal cancer (EC), which primarily affects the upper gastrointestinal tract, is the seventh most common cancer worldwide and a leading cause of death; it was responsible for an estimated 508,585 cancer deaths (5\% of all cancer deaths) in 2018 [1]. An increase in new cases is reported annually [2]. The etiology of EC is multifactorial and involves various factors, such as the host, environment and infectious agents [3-5]. Previous studies have reported that key environmental risk factors for EC incidence include smoking, alcohol consumption, gastroesophageal reflux disease (GERD), a family history of cancer, poor oral hygiene and Campylobacterspp. infection, but the causes of EC vary from country to country [6-15]. 
Numerous studies have found that cigarette smoking and alcohol consumption are significant risk factors for EC (50 times greater than that of individuals who neither drink nor smoke) [16,17].

Epidemiological evidence has shown that bacterial infections are associated with cancer and EC etiology [18-20]. Recently, researchers established that Campylobacter spp., characterized by oral upper digestive tract microbiota, is a major cause of foodborne bacterial infections in developed and developing countries worldwide [21,22]. Campylobacterspp., highly motile, spiral-shaped Gram-negative bacteria, are increasingly being identified as an upper gastrointestinal tract pathogen and subsequent premalignant lesions of the esophagus and prolonged diarrhea, having previously been primarily associated with colonization of the digestive system [23,24]. The epidemiology of symptomatic Campylobacterspp. infection in humans reflects the complexity and variability of Campylobacter sources. Common and major causes of Campylobacter infection include the consumption of undercooked meat, contaminated drinking water, unpasteurized dairy products and direct contract with farm animals [25-27].

Modern researchers have focused on characterizing bacterial communities and identifying differences in healthy and diseased states globally [28]. Various studies have revealed that infection with Gramnegative bacteria in the presence of esophageal abnormalities, such as Barrett's esophagus, plays a vital role in the pathogenesis of inflammation and metaplasia [29,30]. Recently, significant microbial diversity was demonstrated in esophageal squamous cell carcinoma (ESCC), esophagogastric junction (EGJ) cancer and post-ESCC groups, compared to the healthy control group, with the most significant differences observed between the ESCC and healthy control group participants in particular using microbial composition analysis. Thus, monitoring the esophageal microbiota may be a useful method of predicting the recurrence of tumor [31]. In one study, Campylobacter was shown to colonize the esophagus of most patients with Barrett's esophagus and was linked to enteritis, periodontal infection and tumor formation; however, it was not identified in the control group [32]. It has been proposed that infection with C.concisus is a risk factor for the development of Barrett's esophagus (BE), a condition that is needed for the development of EC [33]. By contrast, a reversed trend was reported in one study, with a low rate of Campylobacter spp. identified in the control and cancer patients, together with a high prevalence of GERD and BE [34]. Therefore, there is a significant gap in knowledge regarding microbial influences on $\mathrm{EC}$, with insufficient available data in the literature. Only a few studies have prospectively analyzed the impact of upper digestive tract microbiota on EC risk. Therefore, the primary objective of the current case-control study was to determine the prevalence of Campylobacterspp. in EC tissue using gastroesophageal biopsy specimens obtained from the participants using real-time PCR. A secondary objective was to assess the impact of the combination of Campylobacterspp. infection and environmental factors including oral hygiene on EC incidence in the population of northeastern Thailand.

\section{Materials And Methods}

\section{Study design and participants}

One hundred and five patients with EC and 105 healthy controls were recruited in this hospital-based case-control study, approved by the Khon Kaen University Ethics Committee for Human Research 
(HE621269).

The control group patients were admitted with esophagitis at the same time as the cancer cases. The cases and controls were recruited from Srinagaring Hospital in Khon Kaen province, Northeast Thailand, from 2007 to 2017. Data collection was conducted by trained nurses. The EC cases comprised new patients whose diagnosis was clinically and histologically confirmed according to International Classification of Diseases for Oncology, $3^{\text {rd }}$ Edition (ICD-0-3) codes: C15.3, C15.4, C15.5, C15.8, C15.9 and C16.0. The histological diagnosis was reviewed in each case and confirmed by two pathologists, and the medical reports were obtained from the pathology department.

The control subjects were healthy individuals, confirmed upon physical examination, who underwent clinical and biochemical analysis during the same period that the cases group were recruited. Eligible controls included individuals without a history of gastric or esophageal malignancy. The subjects were randomly sampled from patients undergoing routine endoscopy for investigation of presumed nonmalignant conditions, such as GERD. A criterion was that their esophageal biopsies had to be macroscopically normal in appearance. The participants provided written informed consent to participate in the current study.

Data on the subjects were obtained using an interviewer-based structured questionnaire. Prior to data collection, trained staff served as interviewers to ensure the validity of the questionnaire questions. The demographic information sought included age, gender, height, weight, smoking status, alcohol consumption, a family history of cancer, oral hygiene practices and a history of GERD. Data on cigarette smoking included the age of smoking started, the number of cigarettes smoked per day and smoking duration. A smoker was defined as a current smoker who smoked at least one cigarette per day, having done so for at least six months. Alcohol consumption was divided into two group (drinkers and nondrinkers). Drinking status was defined as drinking alcohol at least once a day for at least six months; nondrinkers were those who consumed alcohol less than once a month. Detailed information was obtained on the participants' oral hygiene practices, for example, the daily frequency with which they brushed their teeth (never, less than once a day, twice or more per day), the type of instrument used to clean their teeth, the regularity of dental visits (never, annually and every 2-5 years) and a previous history of gingivitis or periodontal disease.

\section{Tissue samples}

Formalin-fixed paraffin-embedded (FFPE) samples ( $N=210 ; n=105$ EC samples [case group] and $n=$ 105 normal tissue samples [control group]) were collected retrospectively between 2007 to 2017 and retrieved from paraffin blocks stored at the Department of Pathology, Faculty of Medicine, Khon Kean University. Esophageal squamous cell carcinoma (ESCC) and Esophageal adenocarcinoma samples were categorized in the case group, and normal esophageal tissue samples were assigned to the control group. The samples were initially evaluated by a specialist; thereafter, the diagnoses were confirmed using electronic gastroscopy, a histopathology report and ICD-0-3 guidance. 


\section{Laboratory methods}

\section{DNA extraction and quality control}

DNA was extracted from the FFPE tissue. The FFPE esophageal tissue was cut into $10 \mu \mathrm{M}$ sections placed in a 1.5 microcentifuge tube. Eight sections from each sample were used for DNA extraction. Prior to sectioning, the microtomes and accessories were cleaned using $70 \%$ ethanol alcohol. The DNA of the FFPE tissue samples was extracted using a commercially available system, DNeasy ${ }^{\circledR}$ Blood \& Tissue Kits (Qiagen, Hilden, Germany), according to the manufacturer's instructions. Briefly, eight sections (10 $\mu \mathrm{M}$ each) from each FFPE tissue specimen were deparaffinised in xylene and 95\% ethanol. The deparaffinised tissue was washed twice with $95 \%$ ethanol; $1,000 \mu \mathrm{l}$ of ethanol was added and vortexed for 30 seconds and then centrifuged at 13,000 rpm for five minutes. The tissue pellets were then washed with distilled water and air dried. The recommended protocols for DNA FFPE extraction were followed (Qiagen, DNA FFPE Tissue ${ }^{\circledR}$, Germany). The yields and quality of the DNA isolated during the process were determined using a NanoDrop ${ }^{\circledR}$ ND-1000 Spectrophotometer (Thermo Scientific, Wilmington, USA). The housekeeping gene ( $\beta$-actin) served as an endogenous control to guarantee the DNA quality and was detected using a specific primer (forward 5'- TGTCACAGTGCAAGCTCACTCAGT-3', reverse 5'TCCTGAGGAGAAGTCTGCCGTT-3'), following the protocols described elsewhere [35]. The integrity of the extracted DNA samples was confirmed by amplifying the housekeeping gene ( $\beta$-actin) using SYBR Greenbased real-time polymerase chain reaction (real-time PCR). The DNA samples were stored at $-20^{\circ} \mathrm{C}$ for further analysis.

\section{Campylobacter species detection using a TaqMan ${ }^{\circledR}$ real-time PCR assay}

To detect Campylobacter infection, a TaqMan ${ }^{\circledR}$ real-time PCR detection system, which utilizes fluorogenic-labelled probes, was used to determine the infection agent count [36]. Specific TaqMan ${ }^{\circledR} \mathrm{PCR}$ primers and fluorescently labelled probes (Table 1) were designed using the Oligoware ${ }^{\circledR} 1.0$ software program (Integrated DNA Technology, Coralville, USA). Thereafter, theoretical testing was conducted on the candidate primers and probes, and sequence comparisons were made using the BLAST database (National Institutes of Health, USA). For each infectious agent tested, the TaqMan ${ }^{\circledR}$ PCR assay was performed (a final volume of $20 \mu$ for the PCR reaction). Each reaction comprised $1 \times$ THUNDERBIRD ${ }^{\text {tm }}$ qPCR Mix (Toyobo Co. Ltd., Japan), $10 \mu \mathrm{l}$ of TaqMan ${ }^{\circledR}$ qPCR Mix, $0.3 \mu \mathrm{M}$ of each forward and reverse primer, $0.2 \mu \mathrm{M}$ of TaqMan ${ }^{\circledR}$ probe and $50 \mathrm{ng}$ of DNA template. The amplification, data acquisition and Campylobactergenus DNA analysis was carried out using an Applied Biosystems ${ }^{\circledR} 7500$ flats system.

PCR amplification comprised an initial denaturation cycle at $95^{\circ} \mathrm{C}$ for five minutes, followed by 40 amplification cycles at $95^{\circ} \mathrm{C}$ for 30 seconds, annealing at $55^{\circ} \mathrm{C}$ for 22 seconds and final extension at 72 ${ }^{\circ} \mathrm{C}$ for 30 seconds. The Campylobacter spp. cycling conditions were as follows: initial denaturation with five minutes at $95^{\circ} \mathrm{C}$, followed by 40 amplification cycles at $95^{\circ} \mathrm{C}$ for 30 seconds, a specific $\mathrm{Tm}$ set for each primer for 30 seconds and final extension at $72{ }^{\circ} \mathrm{C}$ for 30 seconds. DNA was extracted from three 
strains following sequencing of the 16S rRNA genes and used as the positive control as in Table1, and molecular distilled water was used as the negative control. Both were utilized in each PCR assay run. The samples and controls were tested in duplicate, and the considered positive were replicated following amplification within a cycle of $<36$.

\section{Statistical analysis}

The demographic characteristics of the subjects were summarized using descriptive statistics. The categorical data were expressed using frequencies and percentages, and the continuous data, such as the age of the subjects, were depicted by mean \pm standard deviation (SD), median, and minimum and maximum range. Bivariate analysis was performed using simple logistic regression to determine the association between the independent factors and EC, without controlling for confounding variables. The crude odds ratio ( $\left(\mathrm{R}_{\text {crude }}\right)$ and the $95 \%$ confidence interval $(95 \% \mathrm{Cl})$ were also calculated. Unconditional multivariable logistic regression was used to compute the adjusted $\mathrm{ORs}\left(\mathrm{OR}_{\mathrm{adj}}\right)$ and $95 \% \mathrm{Cls}$ for the association between EC risk factors and EC, while controlling for the effects of confounding variables. The test statistics were two-sided, and a $p$-value less than 0.05 was considered statistically significant. The statistical analysis was performed using Stata ${ }^{\circledR}$ software (version 13.0).

\section{Results}

\section{Demographic characteristics}

The characteristics of the $105 \mathrm{EC}$ cases and 105 controls are provided in Table 2 . The gender and age distribution differed between the cases and controls (men, $60 \%$ and $47 \%$, respectively; women, $40 \%$ and $53 \%$, respectively). The mean age ( \pm SD) of the men and women was 59.5 years $( \pm 8.7)$ and 56.7 years $( \pm$ 13.2), respectively. The demographics of the subjects' lifestyle habits were evaluated. Drinking status, smoking and poor oral hygiene were more prevalent among the cases than the controls. The frequency of a family history of cancer and a personal history of GERD differed between the cases and controls $(p<$ 0.05). Campylobacter spp. infection was identified in 61 cases (58\%) and 25 controls (24\%).

\section{Risk factors for esophageal cancer}

The primary outcomes of the multivariable analysis are depicted in Table 3. Factors found to be significantly associated with EC were alcohol consumption, smoking status, a family history of cancer in a first-degree relative, a personal history of GERD and poor oral hygiene. The dose-response relationship was statistically significant $(p<0.05)$. Poor oral hygiene increased the odds of developing EC by $49 \%$ $\left(\mathrm{OR}_{\mathrm{adj}}=3.0,95 \% \mathrm{Cl}: 1.44-6.26, p<0.001\right)$.

\section{Campylobacter species infection}

The results of Campylobacterspp. infection relative to EC are detailed in Table 4. Campylobacter infection was associated with an increased risk of EC, and this finding was statistically significant $\left(\mathrm{OR}_{\mathrm{adj}}\right.$ 
$=4.8,95 \% \mathrm{Cl}: 2.26-10.04, p<0.001) . C$. concisus and $C$. rectus were also significantly associated with OC $(p<0.001)$. In addition, subjects who were co-infected with $C$. rectus and $C$. concisus were at increased odds ratio of EC, and the association between this risk factor and EC was statistically significant $\left(\mathrm{OR}_{\mathrm{adj}}=3.4,95 \% \mathrm{Cl}: 1.34-6.61, p=0.002\right)$.

\section{A combination of poor oral hygiene and Campylobacter species infection}

The impact of the combination of poor oral hygiene and infection with Campylobacterspp. as a risk factor for EC was found to be statistically significant at $p<0.001$ (Table 5). The association between EC and poor oral hygiene in combination with $C$. concisus infection was significantly greater than that between $\mathrm{EC}$ and poor oral hygiene in combination with $C$. rectus $\left(\mathrm{OR}_{\mathrm{adj}}=4.2,95 \% \mathrm{Cl}: 1.88-9.47, p<\right.$ $0.001 ; \mathrm{OR}_{\mathrm{adj}}=3.1,95 \% \mathrm{Cl}: 1.33-7.38 ; p=0.008$, respectively). The risk of $\mathrm{EC}$ was slightly higher in subjects who were co-infected with $C$. rectus and $C$. concisus and who practiced poor oral hygiene (an increased $\mathrm{OR})$, and the risk associated with these combined factors was statistically significant $\left(\mathrm{OR}_{\mathrm{adj}}=\right.$ $4.7,95 \% \mathrm{Cl}: 2.41-9.98, p<0.003)$.

\section{Discussion}

The objective of the current study was to evaluate the relationship between environmental risk factors, in particular microbial factors, and their association with the incidence of EC. Smoking status, alcohol use, a family history of cancer in a first-degree relative, a personal history of GERD, poor oral hygiene and Campylobacterspp. infection were established to increase the risk of EC. The association between Campylobacterspp. and EC is inconclusive based on current findings in the literature, and the prevalence of Campylobacterspp. in patients with EC has not yet been reported in Thailand.

Thus, a case-control study was conducted to identify Campylobacter spp. DNA in the esophageal tissue obtained from patients with EC and compare it with that of the controls using PCR. The identification of Campylobacter spp. was confirmed using TaqMan ${ }^{\circledR}$ real-time PCR. The prevalence of Campylobacter spp. in the esophageal tissue of 105 cases and 105 controls was $58 \%$ and $24 \%$, respectively. In the current study, EC was identified more frequently in men than in women. Similar results have been reported in South Thailand [37]. By contrast, a higher incidence of EC in women, compared to men, has been described in Europe [38]. In the current study, the mean age of the EC patients was 59.5 years, which is similar to that of the EC population (a mean age of 57.8 years) recorded using a cancer registry in Khon Kaen, Thailand [39]. Therefore, it was assumed that the finding in the current research on EC cases was representative of this disease in northeast Thailand. This is one of a few studies that has evaluated the relationship between Campylobacterspp. and OC by evaluating esophageal tumor tissue specimens.

The prevalence of Campylobacter spp. was assessed in archived FFPE tissue derived from EC cases diagnosed between 2007 to 2017. A large proportion (41\%) of Campylobacterspp. DNA was identified in the tumor specimens, which demonstrated that Campylobacter spp. infection was associated with EC 
progression, and Campylobacterinfection increased EC risk, and this finding was statistically significant $\left(\mathrm{OR}_{\mathrm{adj}}=4.8,95 \% \mathrm{Cl}: 2.26-10.04, p<0.001\right)$.

Similarly, $C$. concisus and $C$. rectus were significantly associated with $\operatorname{EC}(p<0.001)$. In addition, the risk of EC increased in subjects who were co-infected with $C$. rectus and $C$. concisus and this finding had statistical significance $\left(\mathrm{OR}_{\mathrm{adj}}=3.4,95 \% \mathrm{Cl}: 1.34-6.61, p=0.002\right)$. Specifically, the findings in the current study provided evidence of an association between a combination of poor oral hygiene and Campylobacterspp. infection and EC risk. In general, $C$. rectus and $C$. concisus are associated with poor oral health, including periodontal disease. A prior population-based study identified an association between poor oral health-periodontal disease and orodigestive cancer due to mono- or polymicrobial infection, which resulted in an increase in proinflammatory cytokines, such as interleukin (IL)-1 $\beta$, IL-6, IL-8 and tumor necrosis factor alpha (TNFa), ultimately inducing gene expression relating to cell proliferation, for example, oncogenes [40]. It has been shown that $C$. concisus favors colonization in patients with GERD and Barrett's esophagus (i.e. an increased bacterial count) accompanied by a significant decrease in bacterial count for all other genera [41]. Campylobacterspp. was also identified to a greater extent in the biopsy samples of EC cases compared to those in the control group [42]. C. concisus was shown to induce IL-18, TNFa and p53 expression in Barrett's esophageal cell lines. An in vitro study indicated the relationship between esophageal colonization by $C$. concisus and the epithelial production of TNFa and IL-18, known to induce both an innate and adaptive immune response and to increase CDX1 and COX-2 expression. In turn, this escalates the rate of colonization and chronic inflammation, which has been shown to lead to disease progression in GERD, Barrett's esophagus and EC [43,44].

Thus, the findings in the current study provide evidence of a significant association between a combination of poor oral hygiene-Campylobacter spp. infection and EC risk. Similarly, smoking status, alcohol use, a family history of cancer in a first-degree relative and a personal history of GERD were associated with EC in our sample; the magnitude of these effects was strong enough to achieve statistical significance. Therefore, our results may have policy implications for population-based education and awareness throughout Thailand; however, it will be necessary to confirm these findings using a larger sample size and an experimental design that facilitates an evaluation of the mechanistic pathways that link oral hygiene and EC before serious consideration can be given to implementing interventions.

Limitations and bias should be taken into consideration. A main limitation concerns the retrospective cross-sectional nature of the case-control design; accordingly, a cause-effect relationship between poor oral health and Campylobacter spp. infection and EC risk could be established. Firstly, the control subjects were selected from patients with esophagitis undergoing routine investigations based on a presumption of non-malignancy and good health. Nonetheless, disease misclassification was possible because some of the control subjects may have subsequently been diagnosed with EC because, typically, it is slow-growing and remains clinically 'silent' until the late stages. 
In this study had three important strengths. Firstly, it was a hospital-based case-control study that recruited 105 patients with newly diagnosed EC (the diagnoses were confirmed following clinical and histological analyses after a review of each sample by two pathologists in the Department of Pathology at the Faculty of Medicine, Khon Kaen University) and 105 healthy controls. Secondly, this is the first published study to describe the relationship between poor oral hygiene-infection with Campylobacter spp. and EC in human subjects. In addition, the study demonstrated a dose-response relationship between poor oral hygiene-infection with Campylobacterspp. and EC risk, which is sound evidence of an underlying causal relationship. Thirdly, the data collection was conducted by trained nurses, the laboratory that evaluated Campylobacter spp. infection used real-time PCR (TaqMan ${ }^{\circledR}$ probes), and unconditional logistic regression was employed for the data analysis.

In conclusion, in this study factors alcohol consumption, smoking status, a family history of cancer in a first-degree relative, a personal history of GERD, poor oral hygiene and Campylobacterspp. infection were established to be significant risk factors for EC in Thailand. In addition, the prevalence of Campylobacter spp. in EC cases was significantly higher than that in the controls. Therefore, a combination of poor oral hygiene and infection with Campylobacter spp. were a significant risk factor for EC. Subjects were coinfected with both $C$. rectus and $C$. concisus and characterized by poor oral hygiene behavior were at increased risk of esophageal cancer, and this finding had statistical significance, which suggests that a combination of Campylobacterspp. infection and poor oral health is a potential and significant risk factor for EC. Hence, further prospective cohort studies and studies that utilize larger sample sizes are warranted to confirm the present study's findings and establish the possible mechanisms for Campylobacter spp. etiology and virulence gene infection in EC.

\section{Abbreviations}

${ }^{\circ} \mathrm{C}$ : Celsius; 95\% Cl: 95\% confidence interval; DNA: Deoxyribonucleic acid; OR adj: Adjusted odds ratios; OR c: Crude odds ratios; TaqMan ${ }^{\circledR}$ real-time PCR: Polymerase chain reaction; SD: Standard derivation; FAM, 6-carboxyfluorescein-labelled reporter dye; HEX, 7-hexachloro-6-carboxy-fluorescein-labelled reporter dye; TAMRA, 6-carboxytetramethyl-rhodamine-labelled quencher dye

\section{Declarations}

Ethics approval: This present study was approved by the Khon Kaen University Ethics Committee for Human Research, based on the Declaration of Helsinki and the ICH Good Clinical Practice Guidelines; reference number HE621269.

Consent for publication: Not applicable

Availability of data and material: The datasets during and/or analyzed during the current study available from

the corresponding author on reasonable request. 
Competing interests: All authors declare that they have no conflicts of interest.

Funding: This work was financially supported by Faculty of Medicine, Khon Kaen University, Thailand (Grant no. IN62314)

Authors' contributions: Conceived and designed the experiments: AP., TN., WN., and PS. Collected FFPE esophageal cancer: PU., PS. and AP. Performed the experiments and reviewed statistic analyzed the data: AP, TN, and SC. Wrote the manuscript: AP and TN. All of the authors read and approved the final draft of this manuscript

Acknowledgments: The authors would like to thank Professor Dr. Viraphong Lulitanond and research staff, Research and Diagnostic Center for Emerging Infectious Diseases (RCEID), for their helpful technical support. We thank Department of Epidemiology and Biostatistics, Faculty of Public Health, Khon Kaen University for their contributions to data management and statistical support. We would like to acknowledge Professor John F. Smith for English editing the manuscript via Publication Clinic KKU.

\section{Authors' information}

${ }^{1}$ Department of Microbiology, Faculty of Medicine, Khon Kaen University, Khon Kaen Province, Thailand

${ }^{2}$ Department of Microbiology, Faculty of Medicine, Khon Kaen University, Khon Kaen Province, Thailand

${ }^{3}$ Department of Pathology, Faculty of Medicine, Khon Kaen Universtity, Khon Kaen, Province, Thailand

${ }^{4}$ Department of Microbiology, Faculty of Medicine, Khon Kaen University, Khon Kaen Province, Thailand

${ }^{5}$ Department of Oral Biology, Faculty of Dentistry, Khon Kaen University, Khon Kaen, Province, Thailand

${ }^{6}$ Department of Pathology, Faculty of Medicine, Khon Kaen Universtity, Khon Kaen, Province, Thailand

\section{References}

1. Ferlay, J., Colombet, M., Soerjomataram, l., Mathers, C., Parkin, D. M., Piñeros, M., Znaor, A., \& Bray, F. (2019). Estimating the global cancer incidence and mortality in 2018: GLOBOCAN sources and methods. International journal of cancer, 144(8), 1941-1953. https://doi.org/10.1002/ijc.31937

2. Bray, F., Ferlay, J., Soerjomataram, I., Siegel, R. L., Torre, L. A., \& Jemal, A. (2018). Global cancer statistics 2018: GLOBOCAN estimates of incidence and mortality worldwide for 36 cancers in 185 countries. CA: a cancer journal for clinicians, 68(6), 394-424. https://doi.org/10.3322/caac. 21492

3. Kamangar, F., Chow, W. H., Abnet, C. C., \& Dawsey, S. M. (2009). Environmental causes of esophageal cancer. Gastroenterology clinics of North America, 38(1), 27-vii. https://doi.org/10.1016/j.gtc.2009.01.004 
4. Schneider, J. L., \& Corley, D. A. (2015). A review of the epidemiology of Barrett's oesophagus and oesophageal adenocarcinoma. Best practice \& research. Clinical gastroenterology, 29(1), 29-39. https://doi.org/10.1016/j.bpg.2014.11.008

5. Lee, Y. L., Hu, H. Y., Yang, N. P., Chou, P., \& Chu, D. (2014). Dental prophylaxis decreases the risk of esophageal cancer in males; a nationwide population-based study in Taiwan. PloS one, 9(10), e109444. https://doi.org/10.1371/journal.pone.0109444

6. Lepage C, Drouillard A, Jouve J-L, Faivre J. (2013). Epidemiology and risk factors for ooesophageal adenocarcinoma. Digestive and Liver Disease.45(8):625-29. http://doi.org/10.1016/j.dld.2012.12.020

7. Coleman, H. G., Xie, S. H., \& Lagergren, J. (2018). The Epidemiology of Esophageal Adenocarcinoma. Gastroenterology, 154(2), 390-405. https://doi.org/10.1053/j.gastro.2017.07.046

8. Jiang, X., Tseng, C. C., Bernstein, L., \& Wu, A. H. (2014). Family history of cancer and gastroesophageal disorders and risk of esophageal and gastric adenocarcinomas: a case-control study. BMC cancer, 14, 60. https://doi.org/10.1186/1471-2407-14-60

9. Rustgi, A. K., \& El-Serag, H. B. (2014). Esophageal carcinoma. The New England journal of medicine, 371(26), 2499-2509. https://doi.org/10.1056/NEJMra1314530

10. Bhat, S., Coleman, H. G., Yousef, F., Johnston, B. T., McManus, D. T., Gavin, A. T., \& Murray, L. J. (2011). Risk of malignant progression in Barrett's esophagus patients: results from a large population-based study. Journal of the National Cancer Institute, 103(13), 1049-1057. https://doi.org/10.1093/jnci/djr203

11. Abnet, C. C., Kamangar, F., Islami, F., Nasrollahzadeh, D., Brennan, P., Aghcheli, K., Merat, S., Pourshams, A., Marjani, H. A., Ebadati, A., Sotoudeh, M., Boffetta, P., Malekzadeh, R., \& Dawsey, S. M. (2008). Tooth loss and lack of regular oral hygiene are associated with higher risk of esophageal squamous cell carcinoma. Cancer epidemiology, biomarkers \& prevention: a publication of the American Association for Cancer Research, cosponsored by the American Society of Preventive Oncology, 17(11), 3062-3068. https://doi.org/10.1158/1055-9965.EPI-08-0558

12. Chen, X., Winckler, B., Lu, M., Cheng, H., Yuan, Z., Yang, Y., Jin, L., \& Ye, W. (2015). Oral Microbiota and Risk for Esophageal Squamous Cell Carcinoma in a High-Risk Area of China. PloS one, 10(12), e0143603. https://doi.org/10.1371/journal.pone.0143603

13. Ahn, J., Sinha, R., Pei, Z., Dominianni, C., Wu, J., Shi, J., Goedert, J. J., Hayes, R. B., \& Yang, L. (2013). Human gut microbiome and risk for colorectal cancer. Journal of the National Cancer Institute, 105(24), 1907-1911. https://doi.org/10.1093/jnci/djt300

14. Baba, Y., Iwatsuki, M., Yoshida, N., Watanabe, M., \& Baba, H. (2017). Review of the gut microbiome and esophageal cancer: Pathogenesis and potential clinical implications. Annals of gastroenterological surgery, 1(2), 99-104. https://doi.org/10.1002/ags3.12014

15. Akutko, K., \& Matusiewicz, K. (2017). Campylobacter concisus as the etiologic agent of gastrointestinal diseases. Advances in clinical and experimental medicine: official organ Wroclaw Medical University, 26(1), 149-154. https://doi.org/10.17219/acem/61428 
16. Vioque, J., Barber, X., Bolumar, F., Porta, M., Santibáñez, M., de la Hera, M. G., Moreno-Osset, E., \& PANESOES Study Group (2008). Esophageal cancer risk by type of alcohol drinking and smoking: a case-control study in Spain. BMC cancer, 8, 221. https://doi.org/10.1186/1471-2407-8-221

17. Yang, X., Chen, X., Zhuang, M., Yuan, Z., Nie, S., Lu, M., Jin, L., \& Ye, W. (2017). Smoking and alcohol drinking in relation to the risk of esophageal squamous cell carcinoma: A population-based casecontrol study in China. Scientific reports, 7(1), 17249. https://doi.org/10.1038/s41598-017-17617-2

18. Leon, M. E., Kassa, E., Bane, A., Gemechu, T., Tilahun, Y., Endalafer, N., McKay-Chopin, S., Brancaccio, R. N., Ferro, G., Assefa, M., Ward, E., Tommasino, M., Aseffa, A., Schüz, J., Jemal, A., \& Gheit, T. (2019). Prevalence of human papillomavirus and Helicobacter pylori in esophageal and gastroesophageal junction cancer biopsies from a case-control study in Ethiopia. Infectious agents and cancer, 14. https://doi.org/10.1186/s13027-019-0233-x

19. Snider, E. J., Freedberg, D. E., \& Abrams, J. A. (2016). Potential Role of the Microbiome in Barrett's Esophagus and Esophageal Adenocarcinoma. Digestive diseases and sciences, 61(8), 2217-2225. https://doi.org/10.1007/s10620-016-4155-9

20. Elsalem, L., Jum'ah, A. A., Alfaqih, M. A., \& Aloudat, O. (2020). The Bacterial Microbiota of Gastrointestinal Cancers: Role in Cancer Pathogenesis and Therapeutic Perspectives. Clinical and experimental gastroenterology, 13, 151-185. https://doi.org/10.2147/CEG.S243337

21. Peters, B. A., Wu, J., Pei, Z., Yang, L., Purdue, M. P., Freedman, N. D., Jacobs, E. J., Gapstur, S. M., Hayes, R. B., \& Ahn, J. (2017). Oral Microbiome Composition Reflects Prospective Risk for Esophageal Cancers. Cancer research, 77(23), 6777-6787. https://doi.org/10.1158/0008-5472.CAN17-1296

22. Ngobese B, Zishiri OT, El Zowalaty, ME. (2019). Molecular detection of virulence genes in Campylobacter species isolated from livestock production systems in South Africa. Journal of Integrative Agriculture;62844-3.https://doi.org/10.1016/S2095-3119(19)62844-3

23. Yang, L., Francois, F., \& Pei, Z. (2012). Molecular pathways: pathogenesis and clinical implications of microbiome alteration in esophagitis and Barrett esophagus. Clinical cancer research: an official journal of the American Association for Cancer Research, 18(8), 2138-2144.

https://doi.org/10.1158/1078-0432.CCR-11-0934

24. Samosornsuk, W., Asakura, M., Yoshida, E., Taguchi, T., Nishimura, K., Eampokalap, B., Phongsisay, V., Chaicumpa, W., \& Yamasaki, S. (2007). Evaluation of a cytolethal distending toxin (cdt) gene-based species-specific multiplex PCR assay for the identification of Campylobacter strains isolated from poultry in Thailand. Microbiology and immunology, 51(9), 909-917. https://doi.org/10.1111/j.13480421.2007.tb03974.x

25. Carrique-Mas, J. J., Bryant, J. E., Cuong, N. V., Hoang, N. V., Campbell, J., Hoang, N. V., Dung, T. T., Duy, D. T., Hoa, N. T., Thompson, C., Hien, V. V., Phat, V. V., Farrar, J., \& Baker, S. (2014). An epidemiological investigation of Campylobacter in pig and poultry farms in the Mekong delta of Vietnam. Epidemiology and infection, 142(7), 1425-1436. https://doi.org/10.1017/S0950268813002410 
26. Rosner, B. M., Schielke, A., Didelot, X., Kops, F., Breidenbach, J., Willrich, N., Gölz, G., Alter, T., Stingl, K., Josenhans, C., Suerbaum, S., \& Stark, K. (2017). A combined case-control and molecular source attribution study of human Campylobacter infections in Germany, 2011-2014. Scientific reports, 7(1), 5139. https://doi.org/10.1038/s41598-017-05227-x

27. García-Sánchez, L., Melero, B., \& Rovira, J. (2018). Campylobacter in the Food Chain. Advances in food and nutrition research, 86, 215-252. https://doi.org/10.1016/bs.afnr.2018.04.005

28. Erik J. Snider, Griselda Compres, Daniel E. Freedberg, Hossein Khiabanian, Yael R. Nobel, Stephania Stump, Anne-Catrin Uhlemann, Charles J. Lightdale and Julian A. Abrams (2019). Alterations to the oesophageal microbiome associated with progression from Barrett's esophagus to esophageal adenocarcinoma. Cancer Epidemiol Biomarkers Prev;28(10):1687-93. https://doi.org/ 10.1158/10559965.EPI-19-0008

29. Amir, I., Konikoff, F. M., Oppenheim, M., Gophna, U., \& Half, E. E. (2014). Gastric microbiota is altered in oesophagitis and Barrett's oesophagus and further modified by proton pump inhibitors. Environmental microbiology, 16(9), 2905-2914. https://doi.org/10.1111/1462-2920.12285

30. Peter, S., Pendergraft, A., VanDerPol, W., Wilcox, C. M., Kyanam Kabir Baig, K. R., Morrow, C., Izard, J., \& Mannon, P. J. (2020). Mucosa-Associated Microbiota in Barrett's Esophagus, Dysplasia, and Esophageal Adenocarcinoma Differ Similarly Compared with Healthy Controls. Clinical and translational gastroenterology, 11(8), e00199. https://doi.org/10.14309/ctg.0000000000000199

31. Li, D., He, R., Hou, G., Ming, W., Fan, T., Chen, L., Zhang, L., Jiang, W., Wang, W., Lu, Z., Feng, H., \& Geng, Q. (2020). Characterization of the Esophageal Microbiota and Prediction of the Metabolic Pathways Involved in Esophageal Cancer. Frontiers in cellular and infection microbiology, 10, 268. https://doi.org/10.3389/fcimb.2020.00268

32. Macfarlane, S., Furrie, E., Macfarlane, G. T., \& Dillon, J. F. (2007). Microbial colonization of the upper gastrointestinal tract in patients with Barrett's esophagus. Clinical infectious diseases: an official publication of the Infectious Diseases Society of America, 45(1), 29-38. https://doi.org/10.1086/518578

33. Mozaffari Namin, B., Soltan Dallal, M. M., \& Ebrahimi Daryani, N. (2015). The Effect of Campylobacter concisus on Expression of IL-18, TNF-a and p53 in Barrett's Cell Lines. Jundishapur journal of microbiology, 8(12), e26393. https://doi.org/10.5812/jjm.26393

34. Lv, J., Guo, L., Liu, J. J., Zhao, H. P., Zhang, J., \& Wang, J. H. (2019). Alteration of the esophageal microbiota in Barrett's esophagus and esophageal adenocarcinoma. World journal of gastroenterology, 25(18), 2149-2161. https://doi.org/10.3748/wjg.v25.i18.2149

35. Samareh-Fekri, M., Hashemi Bajgani, S. M., Shafahi, A., Asadi-Zarandi, M., Mollaie, H., \& Jamali Paghalhe, A. (2016). Detection of Helicobacter pylori in the Bronchoalveolar Lavage of Patients with Lung Cancer Using Real-Time PCR. Jundishapur journal of microbiology, 9(11), e32144. https://doi.org/10.5812/jjm.32144

36. Saygun, I., Kubar, A., Sahin, S., Sener, K., \& Slots, J. (2008). Quantitative analysis of association between herpesviruses and bacterial pathogens in periodontitis. Journal of periodontal research, 
43(3), 352-359. https://doi.org/10.1111/j.1600-0765.2007.01043.x

37. Boonyaphiphat, P., Thongsuksai, P., Sriplung, H., \& Puttawibul, P. (2002). Lifestyle habits and genetic susceptibility and the risk of esophageal cancer in the Thai population. Cancer letters, 186(2), 193199. https://doi.org/10.1016/s0304-3835(02)00354-3.

38. Löfdahl, H. E., Lu, Y., \& Lagergren, J. (2008). Sex-specific risk factor profile in oesophageal adenocarcinoma. British journal of cancer, 99(9), 1506-1510.

https://doi.org/10.1038/sj.bjc.6604701

39. Virani, S., Bilheem, S., Chansaard, W., Chitapanarux, I., Daoprasert, K., Khuanchana, S., Leklob, A., Pongnikorn, D., Rozek, L. S., Siriarechakul, S., Suwanrungruang, K., Tassanasunthornwong, S., Vatanasapt, P., \& Sriplung, H. (2017). National and Subnational Population-Based Incidence of Cancer in Thailand: Assessing Cancers with the Highest Burdens. Cancers, 9(8), 108. https://doi.org/10.3390/cancers9080108

40. Hoare, A., Soto, C., Rojas-Celis, V., \& Bravo, D. (2019). Chronic Inflammation as a Link between Periodontitis and Carcinogenesis. Mediators of inflammation, 2019, 1029857. https://doi.org/10.1155/2019/1029857

41. Blackett, K. L., Siddhi, S. S., Cleary, S., Steed, H., Miller, M. H., Macfarlane, S., Macfarlane, G. T., \& Dillon, J. F. (2013). Oesophageal bacterial biofilm changes in gastro-oesophageal reflux disease, Barrett's and oesophageal carcinoma: association or causality? Alimentary pharmacology \& therapeutics, 37(11), 1084-1092. https://doi.org/10.1111/apt.12317

42. Elliott, D., Walker, A. W., O'Donovan, M., Parkhill, J., \& Fitzgerald, R. C. (2017). A non-endoscopic device to sample the oesophageal microbiota: a case-control study. The lancet. Gastroenterology \& hepatology, 2(1), 32-42. https://doi.org/10.1016/S2468-1253(16)30086-3

43. Mozaffari Namin, B., Soltan Dallal, M. M., \& Ebrahimi Daryani, N. (2015). The Effect of Campylobacter concisus on Expression of IL-18, TNF- $a$ and p53 in Barrett's Cell Lines. Jundishapur journal of microbiology, 8(12), e26393. https://doi.org/10.5812/jjm.26393

44. Mozaffari Namin, B., \& Soltan Dallal, M. M. (2018). Campylobacter Concisus and Its Effect on the Expression of CDX1 and COX2. Asian Pacific journal of cancer prevention : APJCP, 19(11), 32113216. https://doi.org/10.31557/APJCP.2018.19.11.3211

45. Lund, M., Nordentoft, S., Pedersen, K., \& Madsen, M. (2004). Detection of Campylobacter spp. in chicken fecal samples by real-time PCR. Journal of clinical microbiology, 42(11), 5125-5132. https://doi.org/10.1128/JCM.42.11.5125-5132.2004

46. Sencimen, M., Saygun, I., Gulses, A., Bal, V., Acikel, C. H., \& Kubar, A. (2014). Evaluation of periodontal pathogens of the mandibular third molar pericoronitis by using real time PCR. International dental journal, 64(4), 200-205. https://doi.org/10.1111/idj.12109

\section{Tables}

Table 1. The detection of bacteria using polymerase chain reaction primers and $\operatorname{TaqMan}^{\circledR}$ probes 


\begin{tabular}{|c|c|c|c|}
\hline $\begin{array}{l}\text { Infection agents } \\
\text { (GenBank accession } \\
\text { numbers) }\end{array}$ & Sequence $\left(5^{\prime}-3^{\prime}\right)$ & $\begin{array}{l}\text { Amplicon } \\
\text { size (bp) }\end{array}$ & References \\
\hline \multicolumn{4}{|c|}{ Campylobacter species (Cam16s RNA) } \\
\hline Forward & 5'-CTGCTTAACACAAGTTGAGTAGG-3' & 267 & \multirow{3}{*}{$\begin{array}{l}\text { Lund et al. } \\
\text { [45] }\end{array}$} \\
\hline Reverse & 5'-TTCCTTAGGTACCGTCAGAA-3' & & \\
\hline Probe & $\begin{array}{l}\text { FAM-5'- } \\
\text { CGCTCCGAAAAGTGTCATCCTCC- } \\
\text { TAMRA -3' }\end{array}$ & & \\
\hline \multicolumn{4}{|c|}{ Campylobacter rectus (AF 035193.1) } \\
\hline Forward & 5'-CACCCGATAACCCTACTСCТССТА-3' & 132 & \multirow{3}{*}{$\begin{array}{l}\text { Sencimen et } \\
\text { al. [46] }\end{array}$} \\
\hline Reverse & 5'-GATCCGTTCCATCAGTACCCACTA-3' & & \\
\hline Probe & $\begin{array}{l}\text { HEX-5'- } \\
\text { CCGGTACCGAATCCTGAGGAACCA- } \\
\text { TAMRA-3' }\end{array}$ & & \\
\hline \multicolumn{4}{|c|}{ Campylobacter concisus (CP012541.1) } \\
\hline Forward & 5'-GCCTAGCTCTTCACTGATAAC-3' & 216 & \multirow{3}{*}{$\begin{array}{l}\text { The current } \\
\text { study }\end{array}$} \\
\hline Reverse & 5'-СССАТАСТТСАТСАСАААССС-3' & & \\
\hline Probe & $\begin{array}{l}\text { FAM-5'- } \\
\text { TACTTGCTCAAGCACTGGCAATA- } \\
\text { TAMRA-3' }\end{array}$ & & \\
\hline
\end{tabular}

FAM, 6-carboxyfluorescein-labelled reporter dye; HEX, 7-hexachloro-6-carboxy-fluorescein-labelled reporter dye; TAMRA, 6-carboxytetramethyl-rhodamine-labelled quencher dye

Table 2. Demographic characteristics of the esophageal cancer cases and controls 


\begin{tabular}{|c|c|c|c|c|c|}
\hline \multirow[t]{2}{*}{ characteristics } & \multicolumn{2}{|c|}{ Cases } & \multicolumn{2}{|c|}{ Controls } & \multirow[t]{2}{*}{ p-value } \\
\hline & \multicolumn{2}{|c|}{$\mathrm{N}=105$} & \multicolumn{2}{|c|}{$\mathrm{N}=105$} & \\
\hline \multicolumn{6}{|l|}{ Gender } \\
\hline Female & 42 & $(40.0 \%)$ & 56 & $(53.3 \%)$ & \multirow[t]{2}{*}{$0.053^{a}$} \\
\hline Male & 63 & $(60.0 \%)$ & 49 & $(46.7 \%)$ & \\
\hline Age $($ mean \pm SD $)$ & \multicolumn{2}{|c|}{$59.5 \pm 8.7$} & \multicolumn{2}{|c|}{$56.7 \pm 13.2$} & $0.012^{b}$ \\
\hline \multicolumn{6}{|l|}{ Drinking status } \\
\hline Non-drinker & 33 & $(31.4 \%)$ & 64 & $(61.0 \%)$ & \multirow[t]{2}{*}{$<0.001^{\mathrm{a}}$} \\
\hline Drinker & 72 & $(68.6 \%)$ & 41 & $(39.0 \%)$ & \\
\hline \multicolumn{6}{|l|}{ Smoking status } \\
\hline Non-smoker & 45 & $(48.2 \%)$ & 72 & $(68.6 \%)$ & \multirow[t]{2}{*}{$<0.001^{\mathrm{a}}$} \\
\hline Smoker & 60 & $(51.8 \%)$ & 33 & $(31.4 \%)$ & \\
\hline \multicolumn{6}{|c|}{ Family history of cancer in first-degree relatives } \\
\hline No & 27 & $(25.7 \%)$ & 60 & $(57.1 \%)$ & \multirow[t]{2}{*}{$<0.001^{\mathrm{a}}$} \\
\hline yes & 78 & $(74.3 \%)$ & 45 & $(42.9 \%)$ & \\
\hline \multicolumn{6}{|c|}{ Personal history of gastroesophageal reflux disease } \\
\hline No & 25 & $(23.8 \%)$ & 65 & $(61.9 \%)$ & \multirow[t]{2}{*}{$<0.001^{\mathrm{a}}$} \\
\hline yes & 80 & $(76.2 \%)$ & 40 & $(38.1 \%)$ & \\
\hline \multicolumn{6}{|l|}{ Poor oral hygiene } \\
\hline No & 33 & $(31.4 \%)$ & 55 & $(52.4 \%)$ & \multirow[t]{2}{*}{$0.002^{\mathrm{a}}$} \\
\hline Yes & 72 & $(68.6 \%)$ & 50 & $(47.6 \%)$ & \\
\hline \multicolumn{6}{|c|}{ Campylobacter genus infection } \\
\hline Negative & 44 & $(41.9 \%)$ & 80 & $(76.2 \%)$ & \multirow[t]{2}{*}{$<0.001^{\mathrm{a}}$} \\
\hline Positive & 61 & $(58.1 \%)$ & 25 & (23.8\%) & \\
\hline
\end{tabular}

${ }^{a} p$; p-value differences between cases and controls were detected using the Chi-squared test.

${ }^{b} p$; p-value differences between cases and controls were detected using the Wilcoxon rank-sum test. 
Table 3. Crude and adjusted odds ratios for the association of esophageal cancer and various risk factors 


\begin{tabular}{|c|c|c|c|c|c|c|c|}
\hline \multirow[t]{2}{*}{ variables } & \multicolumn{2}{|c|}{ Cases } & \multicolumn{2}{|c|}{ Control } & $\begin{array}{l}\mathrm{OR}_{\mathrm{C}} \\
(95 \% \mathrm{Cl})\end{array}$ & $\begin{array}{l}\text { ORadj } \\
\text { (95\%Cl) }\end{array}$ & $\begin{array}{l}P \text { - } \\
\text { value }\end{array}$ \\
\hline & \multicolumn{2}{|c|}{$N=105$} & \multicolumn{4}{|c|}{$\mathrm{N}=105$} & \\
\hline Gender & & & & & & & 0.261 \\
\hline Female & 42 & $(40.0 \%)$ & 56 & (53.3\%) & $\begin{array}{l}1.0 \\
\text { (reference) }\end{array}$ & $\begin{array}{l}1.0 \\
\text { (reference) }\end{array}$ & \\
\hline Male & 63 & $(60.0 \%)$ & 49 & $(46.7 \%)$ & $\begin{array}{l}1.7(0.98- \\
2.96)\end{array}$ & $\begin{array}{l}1.3(0.77- \\
2.53)\end{array}$ & \\
\hline Age (years) & & & & & & & 0.339 \\
\hline$<60$ & 14 & $(13.3 \%)$ & 35 & $(33.4 \%)$ & $\begin{array}{l}1.0 \\
\text { (reference) }\end{array}$ & $\begin{array}{l}1.0 \\
\text { (reference) }\end{array}$ & \\
\hline$\geq 60$ & 91 & $(86.7 \%)$ & 70 & $(66.6 \%)$ & $\begin{array}{l}1.8(0.99- \\
3.01)\end{array}$ & $\begin{array}{l}1.4(0.71- \\
2.81)\end{array}$ & \\
\hline Drinking status & & & & & & & 0.016 \\
\hline Non-drinker & 33 & $(31.4 \%)$ & 64 & $(61.0 \%)$ & $\begin{array}{l}1.0 \\
\text { (reference) }\end{array}$ & $\begin{array}{l}1.0 \\
\text { (reference) }\end{array}$ & \\
\hline drinker & 72 & $(68.6 \%)$ & 41 & (39.0\%) & $\begin{array}{l}3.4(1.93- \\
6.02)\end{array}$ & $\begin{array}{l}3.2(1.25- \\
8.62)\end{array}$ & \\
\hline Smoking status & & & & & & & 0.015 \\
\hline Non-smoker & 45 & $(48.2 \%)$ & 72 & $(68.6 \%)$ & $\begin{array}{l}1.0 \\
\text { (reference) }\end{array}$ & $\begin{array}{l}1.0 \\
\text { (reference) }\end{array}$ & \\
\hline Smoker & 60 & $(51.8 \%)$ & 33 & (31.4\%) & $\begin{array}{l}3.3(1.86- \\
5.77)\end{array}$ & $\begin{array}{l}3.5(1.28- \\
9.56)\end{array}$ & \\
\hline $\begin{array}{l}\text { Family history of cancer in } \\
\text { first-degree relatives }\end{array}$ & & & & & & & 0.001 \\
\hline No & 27 & $(25.7 \%)$ & 60 & (57.1\%) & $\begin{array}{l}1.0 \\
\text { (reference) }\end{array}$ & $\begin{array}{l}1.0 \\
\text { (reference) }\end{array}$ & \\
\hline Yes & 78 & $(74.3 \%)$ & 45 & $(42.9 \%)$ & $\begin{array}{l}3.8(2.15- \\
6.91)\end{array}$ & $\begin{array}{l}3.7 \text { (1.69- } \\
8.12)\end{array}$ & \\
\hline $\begin{array}{l}\text { Personal history of gastro } \\
\text { esophagus reflux diseases } \\
\text { (GERD) }\end{array}$ & & & & & & & 0.008 \\
\hline No & 25 & $(23.8 \%)$ & 65 & $(61.9 \%)$ & $\begin{array}{l}1.0 \\
\text { (reference) }\end{array}$ & $\begin{array}{l}1.0 \\
\text { (reference) }\end{array}$ & \\
\hline Yes & 80 & $(76.2 \%)$ & 40 & (38.1\%) & $\begin{array}{l}4.2(2.86- \\
9.44)\end{array}$ & $\begin{array}{l}2.8(1.29- \\
5.62)\end{array}$ & \\
\hline Poor oral hygiene & & & & & & & $<0.001$ \\
\hline
\end{tabular}




\begin{tabular}{|lllllll|} 
No & 33 & $(31.4 \%)$ & 55 & $(52.4 \%)$ & $\begin{array}{l}1.0 \\
\text { (reference) }\end{array}$ & $\begin{array}{l}1.0 \\
\text { (reference) }\end{array}$ \\
Yes & 72 & $(68.6 \%)$ & 50 & $(47.6 \%)$ & $\begin{array}{l}2.8(1.36- \\
4.21)\end{array}$ & $\begin{array}{l}3.0(1.44- \\
6.26)\end{array}$ \\
\hline
\end{tabular}

ORc: crude odds ratio, ORadj.: adjusted odds ratio, 95\% Cl: $95 \%$ confidence interval,

p-value from unconditional logistic regression

Table 4. The relationship between Campylobacter species and esophageal cancer risk

\begin{tabular}{|c|c|c|c|c|c|c|c|}
\hline \multirow[t]{2}{*}{ Variables } & \multicolumn{2}{|c|}{ Cases } & \multicolumn{2}{|c|}{ Controls } & \multirow[t]{2}{*}{$\mathrm{OR}_{\mathrm{C}}(95 \% \mathrm{Cl})$} & \multirow[t]{2}{*}{ ORadj (95\% Cl) } & \multirow[t]{2}{*}{$P$-value } \\
\hline & \multicolumn{2}{|c|}{$\mathrm{N}=105$} & \multicolumn{2}{|c|}{$N=105$} & & & \\
\hline \multicolumn{8}{|l|}{ Gender } \\
\hline Female & 42 & $(40.0 \%)$ & 56 & $(53.3 \%)$ & 1.0 (reference) & 1.0 (reference) & \multirow[t]{2}{*}{0.261} \\
\hline Male & 63 & $(60.0 \%)$ & 49 & $(46.7 \%)$ & $1.7(0.98-2.96)$ & $1.3(0.77-2.53)$ & \\
\hline \multicolumn{8}{|c|}{ Age (years) } \\
\hline$<60$ & 14 & $(13.3 \%)$ & 35 & $(33.4 \%)$ & 1.0 (reference) & 1.0 (reference) & \multirow[t]{2}{*}{0.339} \\
\hline$\geq 60$ & 91 & $(86.7 \%)$ & 70 & $(66.6 \%)$ & $1.8(0.99-3.01)$ & $1.4(0.71-2.81)$ & \\
\hline \multicolumn{8}{|c|}{ Campylobacter species infection } \\
\hline Negative & 44 & $(41.9 \%)$ & 80 & $(76.2 \%)$ & 1.0 (reference) & 1.0 (reference) & \multirow[t]{2}{*}{$<0.001$} \\
\hline Positive & 61 & $(58.1 \%)$ & 25 & $(23.8 \%)$ & $4.4(2.45-8.03)$ & $4.8(2.26-10.04)$ & \\
\hline \multicolumn{8}{|c|}{ Type of Campylobacter species infection } \\
\hline \multicolumn{8}{|c|}{ Campylobacter rectus infection } \\
\hline Negative & 70 & $(66.7 \%)$ & 90 & $(85.7 \%)$ & 1.0 (reference) & 1.0 (reference) & \multirow[t]{2}{*}{0.027} \\
\hline Positive & 35 & $(33.3 \%)$ & 15 & $(14.3 \%)$ & $3.3(2.25-8.37)$ & $2.8(1.11-6.10)$ & \\
\hline \multicolumn{8}{|c|}{ Campylobacter concisus infection } \\
\hline Negative & 59 & $(56.2 \%)$ & 87 & $(84.8 \%)$ & 1.0 (reference) & 1.0 (reference) & \multirow[t]{2}{*}{0.004} \\
\hline Positive & 46 & $(43.8 \%)$ & 18 & $(15.2 \%)$ & $3.0(1.52-5.93)$ & $3.1(1.42-6.77)$ & \\
\hline \multicolumn{8}{|c|}{ Co-infection ${ }^{d}$} \\
\hline Negative & 74 & $(70.4 \%)$ & 95 & $90.0 \%$ & 1.0 (reference) & 1.0 (reference) & \multirow[t]{2}{*}{0.002} \\
\hline Positive & 31 & $(29.6 \%)$ & 10 & $(10.0 \%)$ & $3.8(1.83-8.63)$ & $3.4(1.34-6.61)$ & \\
\hline
\end{tabular}


ORc, crude odds ratio; ORadj, adjusted odd ratio; 95\% Cl, 95\% confidence interval

$p$-values obtained using unconditional logistic regression

Co-infection with Campylobacter rectus and Campylobacter concisus

Table 5. The relationship between poor oral hygiene behavior and Campylobacter species infection as a risk factor for esophageal cancer

\begin{tabular}{|c|c|c|c|c|c|c|}
\hline \multirow[t]{2}{*}{ Variables } & \multicolumn{2}{|c|}{ Cases } & \multicolumn{2}{|c|}{ Controls } & \multirow[t]{2}{*}{$\mathrm{OR}_{\mathrm{adj}}(95 \% \mathrm{Cl})$} & \multirow[t]{2}{*}{$P$-value } \\
\hline & \multicolumn{2}{|c|}{$N=105$} & \multicolumn{2}{|c|}{$\mathrm{N}=105$} & & \\
\hline \multicolumn{7}{|c|}{ Campylobacterspp. infection plus poor oral hygiene } \\
\hline Negative & 62 & $(59.1 \%)$ & 90 & $(85.7 \%)$ & 1.0 (reference) & \multirow[t]{2}{*}{$<0.001$} \\
\hline Positive & 43 & $(40.9 \%)$ & 15 & $(14.3 \%)$ & $4.7(2.31-9.91)$ & \\
\hline \multicolumn{7}{|c|}{ Type of Campylobacter species infection } \\
\hline \multicolumn{7}{|c|}{ Campylobacter rectus infection plus poor oral hygiene } \\
\hline Negative & 81 & $(77.1 \%)$ & 96 & $(91.4 \%)$ & 1.0 (reference) & \multirow[t]{2}{*}{0.008} \\
\hline Positive & 24 & $(22.9 \%)$ & 9 & $(8.6 \%)$ & $3.1(1.33-7.38)$ & \\
\hline \multicolumn{7}{|c|}{ Campylobacter concisus infection plus poor oral hygiene } \\
\hline Negative & 73 & $(69.5 \%)$ & 95 & $(90.4 \%)$ & 1.0 (reference) & \multirow[t]{2}{*}{$<0.001$} \\
\hline Positive & 32 & $(30.5 \%)$ & 10 & $(9.6 \%)$ & $4.2(1.88-9.47)$ & \\
\hline \multicolumn{7}{|c|}{ Co-infection plus poor oral hygiene ${ }^{c}$} \\
\hline Negative & 69 & $(65.7 \%)$ & 98 & $(93.3 \%)$ & 1.0 (reference) & \multirow[t]{2}{*}{0.003} \\
\hline Positive & 36 & $(34.2 \%)$ & 7 & $(6.7 \%)$ & $4.7(2.41 .-9.98)$ & \\
\hline
\end{tabular}

ORadj, adjusted odds ratio; $95 \% \mathrm{Cl}, 95 \%$ confidence interval

$p$-values were obtained using unconditional logistic regression and were adjusted for gender and age Co-infection with Campylobacter rectus and Campylobacter concisus 